\title{
Morphological and molecular characterization of Haemoproteus coatneyi and Haemoproteus erythrogravidus (Haemosporida: Haemoproteidae) in Passeriformes in Brazil's Atlantic Forest
}

\author{
Caracterização morfológica e molecular de Haemoproteus coatneyi e \\ Haemoproteus erythrogravidus (Haemosporida: Haemoproteidae) em \\ Passeriformes da Mata Atlântica, Brasil
}

Luísa de Oliveira ${ }^{15}$; Glauber Thiago Martins Barino ${ }^{15}$; Mariana Fonseca Rossi; Marta D’Agosto1; Roberto Júnio Pedroso Dias ${ }^{1}$; Huarrisson Azevedo Santos ${ }^{2 *}$ (iD

\begin{abstract}
'Departamento de Zoologia, Instituto de Ciências Biológicas, Universidade Federal de Juiz de Fora - UFJF, Juiz de Fora, MG, Brasi 2Departamento de Epidemiologia e Saúde Pública, Instituto de Veterinária, Universidade Federal Rural do Rio de Janeiro - UFRRJ Seropédica, RJ, Brasil

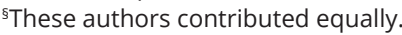

\begin{abstract}
How to cite: Oliveira L, Barino GTM, Rossi MF, D'Agosto M, Dias RJP, Santos HA. Morphological and molecular characterization of Haemoproteus coatneyi and Haemoproteus erythrogravidus (Haemosporida: Haemoproteidae) in Passeriformes in Brazil's Atlantic Forest. Braz J Vet Parasitol 2020; 29(4): e011520. https://doi.org/10.1590/S1984-29612020074
\end{abstract}

\begin{abstract}
Haemoproteus spp. are protozoan parasites found in birds around the world. These parasites are identified through the morphology of gametocytes, phylogenetic analysis based on the mitochondrial cytb gene, and the parasite's geographic distribution. The absence of erythrocytic merogony, high intraspecific genetic variation and low parasitemia in wild birds makes it essential to use integrative approaches that assist in the identification of these parasites. Thus, microscopic and molecular analyses, combined with spatial distribution, were carried out to verify the presence of Haemoproteus spp. in wild birds in Brazil. Light microscopy revealed one Tangara sayaca bird was parasitized by Haemoproteus coatneyi and, two specimens of Zonotrichia capensis presented Haemoproteus erythrogravidus. The morphology of the gametocytes of these two parasitic species showed high similarity. The molecular analysis revealed the presence of one lineage of $H$. coatneyi and two lineages of $H$. erythrogravidus, one of which is considered a new lineage. These lineages were grouped phylogenetically in separate clades, with low genetic divergence, and the $H$. erythrogravidus lineage emerged as an internal group of the lineages of H. coatneyi. The geographic distribution demonstrated that the two species occur in the American continent. This is the first report of $H$. erythrogravidus in Brazil.
\end{abstract}

Keywords: birds, haemosporidians, Tangara sayaca, Zonotrichia capensis, geographic distribution.

\begin{abstract}
Resumo
Haemoproteus spp. são protozoários parasitos encontrados em aves de todo o mundo. A identificação desses parasitos é realizada por meio da morfologia dos gametócitos, da análise filogenética, baseada no gene mitoncodrial cytb e na distribuição geográfica do parasito. A ausência de merogonia eritrocítica, a alta variação genética intraespecífica e a baixa parasitemia em aves silvestres, tornam essencial a utilização de abordagens integrativas que auxiliem na identificação desses parasitos. Assim, análises microscópicas e moleculares, aliadas à distribuição espacial, foram realizadas para verificar a presença de Haemoproteus spp. em aves silvestres no Brasil. A microscopia óptica demonstrou que uma ave Tangara sayaca estava parasitada por Haemoproteus coatneyi, e dois espécimes de Zonotrichia capensis apresentavam Haemoproteus erythrogravidus, cujas morfologias dos gametócitos apresentaram alta similaridade. A análise molecular recuperou uma linhagem de $H$. coatneyi e duas linhagens de $H$. erythrogravidus, sendo uma dessas considerada nova linhagem. Essas linhagens se agruparam
\end{abstract}

Received May 13, 2020. Accepted July 10, 2020.

*Corresponding author: Huarrisson Azevedo Santos. E-mail: huarrisson@yahoo.com.br

This is an Open Access article distributed under the terms of the Creative Commons Attribution License, which permits unrestricted use, distribution, and reproduction in any medium, provided the original work is properly cited. 
filogeneticamente em clados separados, apresentando baixa divergência genética, sendo que as linhagens de $H$. erythrogravidus emergiram como grupo interno às linhagens de $H$. coatneyi. A distribuição geográfica demonstrou que as duas espécies estão ocorrendo no continente americano. Este é o primeiro relato de $H$. erythrogravidus no Brasil.

Palavras-chave: aves, hemosporídeos, Tangara sayaca, Zonotrichia capensis, distribuição geográfica.

\section{Introduction}

Haemosporidians (Apicomplexa: Haemosporida) are among the most common hemoparasites in wild birds (Valkiūnas, 2005). The genus Haemoproteus itself comprises more than 140 species of protozoan hemoparasites. These parasites can be found in birds from all geographic regions of the world, with the exception of Antarctica (Garnham, 1966; Dimitrov et al., 2014). The lifecycle of parasites of this genus is heteroxenous, with the asexual phase occurring in tissue cells and erythrocytes of the vertebrate host and the sexual phase occurring in hematophagous Diptera (Garnham, 1966). Specific relationships with groups of vertebrate hosts led to the division of the Haemoproteus genus into two subgenera, Haemoproteus and Parahaemoproteus (Garnham, 1966). Phylogenetic studies later confirmed this hypothesis based on the specificity of the vector. The parasites species transmitted by louse flies of the family Hippoboscidae belong to the subgenus Haemoproteus and those transmitted by biting midges of the family Ceratopogonidae are classified in the subgenus Parahaemoproteus (Martinsen et al., 2008; SantiagoAlarcon et al., 2010).

The traditional taxonomic classification of avian haemosporidians is based on life history and morphology. The main form of identification of haemosporidian species is still based on the morphological characterization of blood stages found in the vertebrate host, combined with the molecular characterization of species (Valkiūnas \& lezhova, 2018). However, several factors can influence or hinder the correct identification of these hemoparasites. In the case of the genus Haemoproteus, for example, the morphological description is restricted to the characteristics of the gametocytes, given that the species of this group do not perform erythrocytic merogony and that they have few characters for differentiation at the species level. Moreover, some of these characters are extremely similar, making their identification difficult, especially in cases of cryptic species (Garnham, 1966; Dimitrov et al., 2016). In addition, wild birds generally have lower parasitemia than captive birds or those used in experimental infections to assess the susceptibility of the host to haemosporidians. This low parasitemia can make it impossible to differentiate species, given the absence of all erythrocytic stages or mature gametocytes (Dimitrov et al., 2016).

Two species of the genus Haemoproteus that infect wild birds are Haemoproteus coatneyi and Haemoproteus erythrogravidus. Haemoproteus coatneyi has been described only through morphological analysis (Burry-Caines \& Bennett, 1992), whereas $H$. erythrogravidus has been described by morphological and molecular data based on a cytb fragment, and also through complete mitochondrial genome sequencing (Mantilla et al., 2016). According to these authors, $H$. erythrogravidus is closely related to $H$. coatneyi, distinguished morphologically by the formation of a marked protrusion on the envelope of infected erythrocytes by the majority of developing gametocytes and by the extremely attenuated width of the growing dumbbell-shaped macro and microgametocytes.

Host specificity and geographic distribution are currently not considered valid taxonomic characters for identifying haemosporidian species. However, these aspects have been used successfully in the taxonomy of Haemoproteidae (Valkiūnas \& Ashford, 2002) and can be used as additional information in molecular and morphological methods. Haemoproteus coatneyi does not appear to be host-specific, and has been recorded in more than 20 avian species (Valkiūnas, 2005). However, only two hosts (Zonotrichia capensis and Anisognathus somptuosus) have been recorded for H. erythrogravidus (MalAvi, 2020; GenBank, 2020), although there are several studies of this species. In addition, $\mathrm{H}$. coatneyi has a greater geographic distribution, and has been recorded in Canada, the United States, Mexico, Colombia and Peru, while H. erythrogravidus has been identified only in Colombia, Peru and Brazil (MalAvi, 2020; GenBank, 2020).

Thus, integrated methodologies that perform morphological and molecular analysis of parasite lineages, specificity of the host-parasite relationship, and geographic distribution may be essential for the identification of very similar species of the genus Haemoproteus. In order to improve the understanding of infection by Haemoproteus spp. in wild birds, this study focused on the morphological and molecular characterization of Haemoproteus spp. and compared the data obtained with previous records in different hosts and geographic locations. 


\section{Material and methods}

\section{Area of study and blood collection}

The birds were caught between the years 2013 and 2015 in fragments of Atlantic Forest in the Zona da Mata of Minas Gerais, Brazil, as follows: Sítio Paraíso da Barra - Chácara, 21.68' S, 43.22' W, 796 m altitude; Sítio Vista Alegre - Juiz de Fora, 21. 48' S, 43. 15' W, 494 m altitude; Granja Passarada, Juiz de Fora, 21. 48' S, 43. 19' W, 615 m altitude; Botanical Garden of the Universidade Federal de Juiz de Fora (UFJF) - Juiz de Fora, 21. 43' S, 43. 22 W, 715 m altitude and Fazenda Volta Grande - Santa Bárbara do Monte Verde, 21. 58' S, 43. 41' W, 798 m altitude. The birds were trapped using mist nets and were marked with rings in order to avoid recapturing them. The bird species were identified according to Ridgely \& Tudor (2009) and Sigrist (2014), based on morphometric analysis and phenotypic characteristics such as size, plumage color, beak and legs morphology. Blood samples were collected by brachial venipuncture from the species: Arremon semitorquatus, Zonotrichia capensis and Ammodramus humeralis, belonging to the family Passerellidae, and Tangara sayaca, belonging to the family Thraupidae. Immediately after preparing blood smears on slides, they were air dried and then fixed in absolute methanol for 3 min at the same collection site. For the molecular procedures, approximately $30 \mu \mathrm{l}$ of blood were placed in microtubes without anticoagulants and stored in a freezer at $-20^{\circ} \mathrm{C}$. After collecting the blood samples, the birds were immediately released into nature. All the sampling procedures and methods were evaluated and approved by the Ethics Committee on Animal Experimentation of the Federal University of Juiz de Fora - UFJF (Protocol No. 042/2012) and by the Biodiversity Authorization and Information System - SISBIO (Protocol Nos. 29268-3 and 29268-4).

\section{Morphological and morphometric analyses}

Blood smears were stained with Giemsa solution $\left(\right.$ SIGMA $\left.^{\circledR}\right)$ diluted in distilled water at a ratio of 1: 9. The slides were examined under Olympus BX-51 light microscope coupled to an Olympus Evolt E-330 digital camera to record the evolutionary forms of parasites. The slides were then examined under 600X magnification for $20 \mathrm{~min}$ to detect the presence of hemoparasites. Then, 100 microscopic fields were observed under 1000x magnification to calculate the parasitemia. Image-Pro Plus 6.0 imaging software was used to perform the morphometric analysis of gametocytes, following parameters set by Valkiūnas (2005).

\section{DNA extraction, PCR and sequencing}

Only the samples that were positive for the presence of gametocytes in blood smears were subjected to molecular analysis. DNA was extracted from a $20 \mu \mathrm{l}$ blood sample from each bird, using Wizard ${ }^{\circledR}$ Genomic DNA purification kit (Promega ${ }^{\circledR}$, Sao Paulo, Brazil), according to the manufacturer's recommendations. DNA was quantified by spectrophotometry on a Nanodrop ND-2000 ${ }^{\circledR}$ spectrophotometer (ThermoScientific, Wilmington, $D E, ~ U S A)$. The total DNA concentration was standardized to $100 \mathrm{ng} / \mu \mathrm{L}$ and stored at $-20^{\circ} \mathrm{C}$ for further amplification by PCR. A 618 bp fragment of the mitochondrial cytb gene of the haemosporidian parasites was amplified using nested PCR. The primers used in the first reaction, HaemFNI (5'-CATATATTAAGAGAAITATGGAG-3') and HaemNR3 (5'-ATAGAAAGATAAGAAATACCATTC-3'), served to amplify species of the genera Plasmodium, Haemoproteus and Leucocytozoon (Hellgren et al., 2004). The reaction was carried out in a final volume of $25 \mu \mathrm{L}$, containing: $12.5 \mu \mathrm{L}$ of $1 \mathrm{X}$ of Go Taq ${ }^{\circledR}$ Green Master Mix (Promega, MA, USA); $2.5 \mu \mathrm{L}$ of ultra-pure water; $1.0 \mu \mathrm{M}$ of each primer; and $5 \mu \mathrm{L}$ of genomic DNA (20-100 ng). In the second reaction, the primers HaemF (5'-ATGGTGCTTTCGATATATGCATG-3') and HaemR2 (5'-GCATTATCTGGATGTGATAATGGT-3') were used to amplify a fragment of approximately $479 \mathrm{bp}$ of the Plasmodium and Haemoproteus cytb genes (Bensch et al., 2000). The reaction was carried out in a final volume of $25 \mu \mathrm{L}$, containing: $12.5 \mu \mathrm{L}$ of $1 \mathrm{X}$ of Go Taq ${ }^{\circledR}$ Green Master Mix; $0.5 \mu \mathrm{M}$ of each primer; and $2 \mu \mathrm{L}$ of the product of the first reaction. Nuclease-free water was used in the amplification reactions for the negative control and DNA extracted from a sample of Plasmodium (Haemamoeba) gallinaceum obtained from an experimental infection study conducted by the Federal University of Minas Gerais (Brazil) was used as a positive control (Rodrigues et al., 2020).

The following amplification conditions were established for the two reactions: $94^{\circ} \mathrm{C}$ for 3 minutes; 35 cycles of $94^{\circ} \mathrm{C}$ for 30 seconds; $52^{\circ} \mathrm{C}$ for 30 seconds; $72^{\circ} \mathrm{C}$ for 45 seconds; and a final extension at $72^{\circ} \mathrm{C}$ for 10 minutes. The PCR products were separated by electrophoresis on $2 \%$ agarose gel, stained with Blue Green Loading Dye I (LGC Biotecnologia ${ }^{\circledR}$, Cotia, São Paulo, Brazil) and examined under ultraviolet light using a GE Healthcare ${ }^{\circledR}$ UV transilluminator. The products amplified in the second PCR reaction were purified with an QIAquick ${ }^{\circledR}$ Purification 
Kit (Qiagen ${ }^{\circledast}$, São Paulo, Brazil), and subjected to bidirectional sequencing in a 3130xL Genetic Analyzer (Applied Biosystems ${ }^{\circledR}$, Carlsbad, California), by Sanger sequencing approach (Sanger et al., 1977), following the manufacturer's instructions.

\section{Phylogenetic analyses}

Phylogenetic reconstructions were performed using a dataset containing 129 sequences attributed to Haemoproteus morphospecies, including all $H$. coatneyi $(n=44)$ and $H$. erythrogravidus $(n=6)$ sequences available in the MalAvi and GenBank databases (accessed on March 26, 2020), as well as the three sequences obtained in this study. The sequences of other haemosporidians amplified during the molecular analysis were automatically excluded. Three sequences of Plasmodium sp. morphotypes and one sequence of Leucocytozoon buteonis were used as outgroups.

Using the standard configuration, the sequences were aligned in the MAFFT software (Katoh et al., 2019) and then visually inspected. After removing poorly aligned sites with Gblocks server (Talavera \& Castresana, 2007), a matrix with $479 \mathrm{bp}$ was obtained. The phylogeny of Haemoproteus was analyzed by Bayesian inference using MrBayes software in XSEDE v. 3.2.6 (Ronquist et al., 2012), available on the CIPRES Portal. A trillion generations were carried out in two simultaneous and independent Markov Chain Monte Carlo simulations, excluding 25\% of the trees generated ("Burn-in"), using the GTR + GAMMA + I model, with 4 gamma categories (Tavaré, 1986; Yang, 1994). The best model of nucleotide substitution was evaluated using the Jmodel Test software implemented in MEGA X (Kumar et al., 2018). The resulting trees were viewed and edited using the FigTree 1.4.4 software. To calculate the genetic divergence between the lineages obtained in this study and others already deposited in databases, the MEGA X software (Kumar et al., 2018) was used, following the program's standard configuration.

\section{Results}

Blood smears from 65 birds were examined, 37 of which were Tangara sayaca (Thraupidae), 28 Passerellidae including 1 Ammodramus humeralis, 12 Arremon semitorquatus and 15 Zonotrichia capensis. The average prevalence found in the family Thraupidae was $2.70 \%(n=1)$ with $0.04 \%$ parasitemia, and that in the family Passerellidae was $7.14 \%(n=2)$, with parasitemia ranging from 0.15 to $0.36 \%$.

The quality of blood smears and precise microscopic examination permitted confirmation of a single infection by Haemoproteus coatneyi in one T. sayaca (Figure 1) and of Haemoproteus erythrogravidus in two Z. capensis (Figures 2 and 3 ). The main similarities between the two parasite species were young and mature gametocytes with

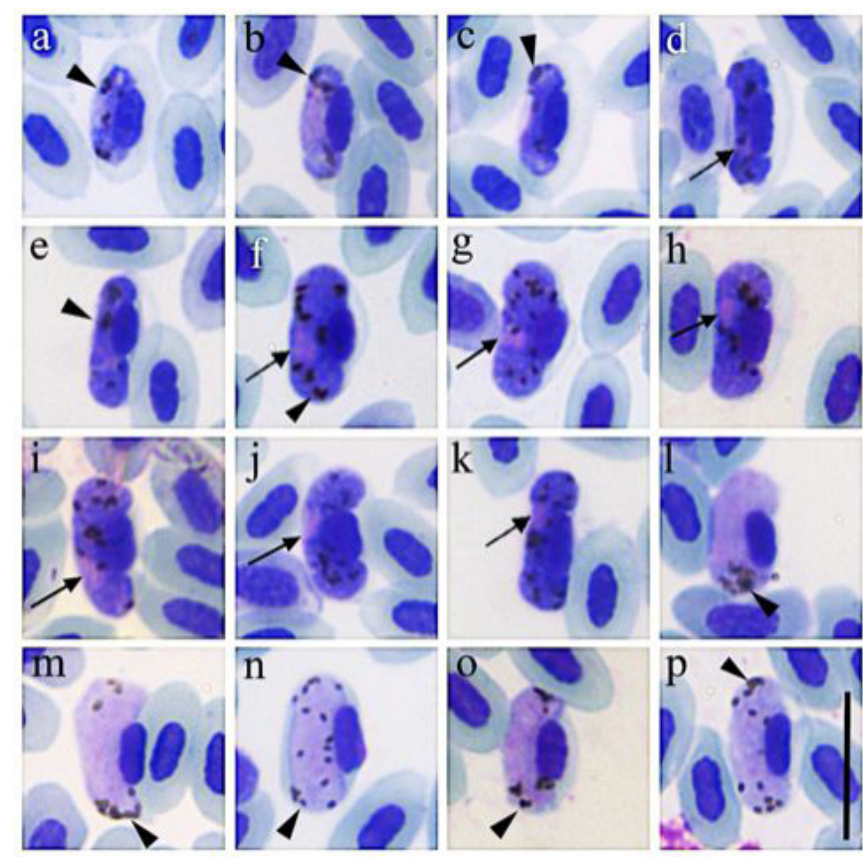

Figure 1. Haemoproteus coatneyi in the blood of Tangara sayaca (lineage TSJB01). Young and growing gametocytes (a - d); macrogametocytes $(e-k)$; microgametocytes $(\mathrm{l}-\mathrm{p})$. Arrowheads indicate the pigment granules. Arrows indicate the nucleus of the parasites. Bar $=12 \mu \mathrm{m}$. 
longitudinal growth, adhered to the nucleus and in a dumbbell-shaped, nucleus subterminal to terminal position in the macrogametocytes, which were indistinguishable in the microgametocytes, and pigment granules randomly distributed in the macrogametocyte cytoplasm and generally grouped at the microgametocytes poles. Some mature gametocytes of the two parasites also showed a slight constriction in the central part of the parasite and a tendency to form a protrusion similar to a "balloon" on the non-parasitized side of the erythrocyte. The vacuoles in the cytoplasm was verified only in H. erythrogravidus.

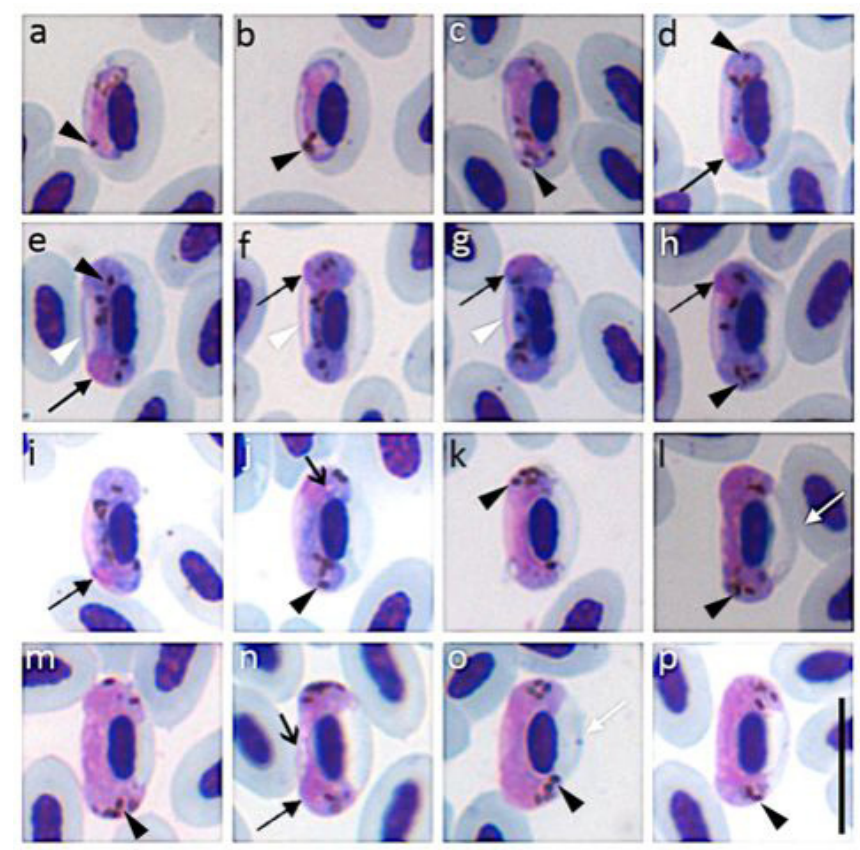

Figure 2. Haemoproteus erythrogravidus in the blood of Zonotrichia capensis (lineage ZCSB01). Young gametocytes (a - d); macrogametocytes $(e-j)$; microgametocytes $(k-p)$. Black arrowheads indicate pigment granules. Black arrow indicates the parasite's nucleus. White arrowheads indicate attenuation in the central part of the gametocytes. Black arrows with open heads indicate vacuoles. White arrows indicate protrusions formed in the infected erythrocytes. Bar $=11 \mu \mathrm{m}$.
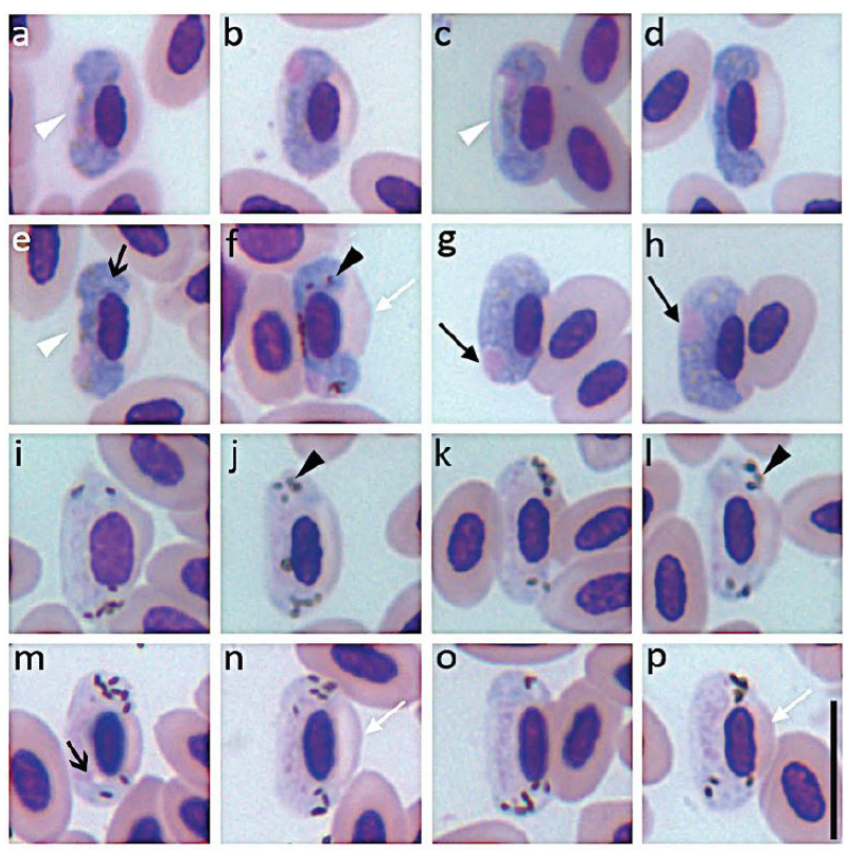

Figure 3. Haemoproteus erythrogravidus in the blood of Zonotrichia capensis (lineage ZCSB02). Young gametocytes (a - d); macrogametocytes $(e-j)$; microgametocytes $(k-p)$. White arrowheads indicate attenuation in the central part of the gametocytes. Black arrow indicates the parasite's nucleus. Black arrows with open heads indicate vacuoles. Black arrow heads indicate pigment granules. White arrows indicate protrusions formed in the infected erythrocytes. Bar $=11 \mu \mathrm{m}$. 
The parasite morphometry measured during the microscopic analysis was compared to the original descriptions of $H$. coatneyi and $H$. erythrogravidus, and is shown in Table 1.

In the molecular analysis, three Haemoproteus spp. lineages were observed. The TSJB01 lineage corresponds to the morphospecies described in T. sayaca (Figure 1). The ZCSB01 and ZCSB02 lineages correspond to the morphospecies described in Z. capensis (Figures 2 and 3). The sequences obtained were deposited in the GenBank database under access numbers MT656006 (TSJB01), MT656007 (ZCSB01) and MT656008 (ZCSB02). The chromatograms analysis confirmed the presence of a single infection in the absence of double peaks in both directions, forward and reverse. The ZCSB02 lineage did not show $100 \%$ similarity with any other one previously included in the genetic databases (MalAvi and GenBank), as is therefore considered a new lineage.

In the phylogenetic reconstruction (Figure 4), the lineages obtained from the databases, together with our lineages of H. coatneyi and H. erythrogravidus, were grouped into four clades (Figure 4; Clades I - IV). Clade I, in which the new TSJB01 lineage was inserted, was composed of $20 \mathrm{H}$. coatneyi lineages. Six lineages of $H$. erythrogravidus were grouped in clade II, including our ZCSB01 and ZCSB02 (II-a) lineages, in addition to 8 lineages of H. coatneyi (II-b). Clade III was composed of $14 \mathrm{H}$. coatneyi lineages. Clade IV was composed of two $\mathrm{H}$. coatneyi lineages and one Haemoproteus cyanomitrae lineage. It should be kept in mind that the clade that groups the H. erythrogravidus (II-a) lineage emerged as an internal group of a larger clade that also contains of $H$. coatneyi lineages (clade II). Furthermore, in clades III and IV, both $H$. coatneyi lineages showed a lineage of the species Haemoproteus tartakovskyi.

Table 1. Comparative morphometry of the gametocytes of Haemoproteus coatneyi in Tangara sayaca and Haemoproteus erythrogravidus in Zonotrichia capensis.

\begin{tabular}{|c|c|c|c|c|}
\hline Characteristic & $\begin{array}{l}\text { H. coatneyi } \\
\text { (This study) }\end{array}$ & $\begin{array}{c}\text { H. coatneyi } \\
\text { Burry-Caines \& } \\
\text { Bennett (1992) }\end{array}$ & $\begin{array}{l}\text { H. erythrogravidus a } \\
\text { (This study) }\end{array}$ & $\begin{array}{l}\text { H. erythrogravidus } \\
\text { Mantilla et al. (2016) }\end{array}$ \\
\hline $\begin{array}{l}\text { Uninfected } \\
\text { erythrocytes }\end{array}$ & $n=21$ & $n=135$ & $n=21$ & $n=25$ \\
\hline Length & $10.9-13(11.9 \pm 0.5)$ & $11.9(0.8)$ & $10.1-11.9(11 \pm 0.5)$ & $10.3-11.7(10.9 \pm 0.4)$ \\
\hline Width & $6-7.1(6.3 \pm 0.3)$ & $6.2(0.6)$ & $5.6-6.7(6.2 \pm 0.3)$ & $5.8-6.5(6.1 \pm 0.2)$ \\
\hline Area & $53.6-71.6(60.9 \pm 3.8)$ & $59.2(7.4)$ & $46.7-60.6(55.2 \pm 3.7)$ & $41.8-56.3(47.9 \pm 3.7)$ \\
\hline \multicolumn{5}{|l|}{$\begin{array}{l}\text { Nucleus of uninfected } \\
\text { erythrocytes }\end{array}$} \\
\hline Length & $5.3-6.4(5.8 \pm 0.3)$ & $5.5(0.5)$ & $5.1-6.1(5.6 \pm 0.3)$ & $4.7-5.6(5.1 \pm 0.1)$ \\
\hline Width & $2.3-3.1(2.6 \pm 0.2)$ & $2.4(0.3)$ & $2.4-3.1(2.7 \pm 0.2)$ & $1.9-2.4(2.1 \pm 0.1)$ \\
\hline Area & $11.6-15.3(13.4 \pm 1)$ & $11.0(1.8)$ & $11.6-14.2(13.1 \pm 0.8)$ & $7.5-9.1(8.2 \pm 0.5)$ \\
\hline Macrogametocytes & $n=21$ & $n=150$ & $n=21$ & $n=25$ \\
\hline \multicolumn{5}{|l|}{ Infected erythrocytes } \\
\hline Length & $11.2-13.3(12.4 \pm 0.5)$ & $12.3(0.9)$ & $11-13(11.8 \pm 0.5)$ & $10.3-11.7(11.1 \pm 0.5)$ \\
\hline Width & $4.7-7.1(5,9 \pm 0.6)$ & $6.2(0.7)$ & $5-7.4(6.4 \pm 0.7)$ & $5.4-7.2(6.4 \pm 0.7)$ \\
\hline Area & $54.1-74.1(63.4 \pm 6.1)$ & $63.4(8.7)$ & $52.7-72.1(64.2 \pm 5.2)$ & $49.6-56.7(52.7 \pm 2.1)$ \\
\hline \multicolumn{5}{|l|}{$\begin{array}{l}\text { Nucleus of infected } \\
\text { erythrocytes }\end{array}$} \\
\hline Length & $4.4-5.7(5.1 \pm 0.3)$ & $5.4(0.5)$ & $5.1-6.1(5.6 \pm 0.3)$ & $4.1-5(4.6 \pm 0.2)$ \\
\hline Width & $1.7-2.7(2.3 \pm 0.2)$ & $2.3(0.4)$ & $2.3-3.6(2.7 \pm 0.3)$ & $2-2.2(2.1 \pm 0.05)$ \\
\hline Area & $9.1-12.8(10.4 \pm 1.1)$ & $10.6(2.1)$ & $10.5-17(12.8 \pm 1.3)$ & $6.4-8(7.4 \pm 0.5)$ \\
\hline
\end{tabular}

aAll measurements are provided in minimum and maximum values. The averages are in parentheses together with the standard deviation; ${ }^{b}$ Range of variation and the average value of the nuclear displacement ratio (NDR) of infected erythrocytes which is calculated according to the formula: NDR $=2 x /(x+y)$ Bennett \& Campbell (1972). $n=$ Number of gametocytes, macrogametocytes and microgametocytes measured. 
Table 1. Continued...

\begin{tabular}{|c|c|c|c|c|}
\hline Characteristic & $\begin{array}{l}\text { H. coatneyi a } \\
\text { (This study) }\end{array}$ & $\begin{array}{c}\text { H. coatneyi } \\
\text { Burry-Caines \& } \\
\text { Bennett (1992) }\end{array}$ & $\begin{array}{l}\text { H. erythrogravidus a } \\
\text { (This study) }\end{array}$ & $\begin{array}{l}\text { H. erythrogravidus } \\
\text { Mantilla et al. (2016) }\end{array}$ \\
\hline Gametocytes & $n=21$ & $n=150$ & $n=21$ & $n=25$ \\
\hline Length & $11.4-15(13.1 \pm 1.1)$ & $16.5(3.4)$ & $11.4-14.1(12.9 \pm 0.7)$ & $10.3-12(11.1 \pm 0.6)$ \\
\hline Width & $1.5-3.2(2.1 \pm 0.4)$ & $2.0(0.9)$ & $0.9-2.1(1.4 \pm 0.3)$ & $2.3-7.2(4.1 \pm 1.7)$ \\
\hline Area & $30.8-50.6(36.8 \pm 5.9)$ & 39.4 (7.9) & $26.3-37.8(31.7 \pm 3.8)$ & $34.3-40(36.9 \pm 1.8)$ \\
\hline \multicolumn{5}{|l|}{$\begin{array}{c}\text { Nucleus of } \\
\text { Gametocytes }\end{array}$} \\
\hline Length & $1.3-3.3(2.2 \pm 0.5)$ & $2.4(0.6)$ & $1.3-3(2.2 \pm 0.4)$ & $1.4-3.1(2.2 \pm 0.4)$ \\
\hline Width & $0.7-2.0(1.2 \pm 0.3)$ & $2.1(0.5)$ & $0.8-1.9(1.4 \pm 0.3)$ & $1-2.2(1.6 \pm 0.39)$ \\
\hline Area & $1.4-4.9(2.8 \pm 0.9)$ & $4.4(1.6)$ & $1.5-4.1(2.8 \pm 0.8)$ & $2.3-4.5(3.6 \pm 0.7)$ \\
\hline No. Pigment granules & $9-17(13 \pm 2.7)$ & $11.6(2.9)$ & $8-14(11 \pm 1.6)$ & $12-17(13.5 \pm 1.6)$ \\
\hline $\mathrm{NDR}^{\mathrm{b}}$ & $0.4-1(0.8 \pm 0.2)$ & $0.8(0.2)$ & $0.8-1.3(1 \pm 0.1)$ & $0.5-0.8(0.6 \pm 0.1)$ \\
\hline Microgametocytes & $n=21$ & - & $n=21$ & $n=11$ \\
\hline \multicolumn{5}{|l|}{ Infected erythrocytes } \\
\hline Length & $11.7-13.4(12.6 \pm 0.5)$ & - & $11.1-12.9(12 \pm 0.5)$ & $13.8-16.9(15.3 \pm 1)$ \\
\hline Width & $5.1-7.7(6.4 \pm 0.8)$ & - & $6-7.7(6.8 \pm 0.4)$ & $6.8-8.4(7.6 \pm 0.6)$ \\
\hline Area & $52.5-78.9(67.4 \pm 7.5)$ & - & $56.6-74(65.8 \pm 4.2)$ & $36.7-45.9(40.6 \pm 2.9)$ \\
\hline \multicolumn{5}{|l|}{$\begin{array}{l}\text { Nucleus of infected } \\
\text { erythrocytes }\end{array}$} \\
\hline Length & $5.1-6(5.5 \pm 0.3)$ & - & $5.2-6.1(5.7 \pm 0.3)$ & $6.2-8.2(6.9 \pm 0.6)$ \\
\hline Width & $2.1-3(2.5 \pm 0.2)$ & - & $2.5-3.7(2.9 \pm 0.3)$ & $2.2-3.1(2.6 \pm 0.3)$ \\
\hline Area & $10.9-13.7(12.3 \pm 0.7)$ & - & $11.1-16.9(13.7 \pm 1.5)$ & $15.4-21.7(18 \pm 2.1)$ \\
\hline Gametocytes & $n=21$ & - & $n=21$ & $n=11$ \\
\hline Length & $12.3-14.9(13.4 \pm 0.8)$ & - & $12.9-15.4(14.2 \pm 0.9)$ & $8.4-12.1(10.4 \pm 1.2)$ \\
\hline Width & $1.7-4.3(2.9 \pm 0.8)$ & - & $2.5-3.7(2.9 \pm 0.3)$ & $0.7-3.3(2.1 \pm 0.7)$ \\
\hline Area & $31.1-54(43.9 \pm 6.6)$ & - & $30-44.1(36.5 \pm 3.9)$ & $21.3-30.6(27.4 \pm 2.7)$ \\
\hline $\begin{array}{l}\text { Nucleus of } \\
\text { Gametocytes }\end{array}$ & - & - & - & - \\
\hline Length & - & - & - & - \\
\hline Width & - & - & - & - \\
\hline Area & - & - & - & - \\
\hline $\begin{array}{l}\text { Number of Pigment } \\
\text { granules }\end{array}$ & $9-16(12.2 \pm 2.1)$ & - & $7-13(9.7 \pm 1.8)$ & $8-15(10 \pm 1.2)$ \\
\hline $\mathrm{NDR}^{\mathrm{b}}$ & $0-0.9(0.4 \pm 0.2)$ & - & $0.7-1.2(0.9 \pm 0.1)$ & $0.7-1.2(0.9 \pm 0.1)$ \\
\hline
\end{tabular}

aAll measurements are provided in minimum and maximum values. The averages are in parentheses together with the standard deviation; ${ }^{\mathrm{b}} \mathrm{Range}$ of variation and the average value of the nuclear displacement ratio (NDR) of infected erythrocytes which is calculated according to the formula: NDR $=2 x /(x+y)$ Bennett \& Campbell (1972). $n=$ Number of gametocytes, macrogametocytes and microgametocytes measured. 


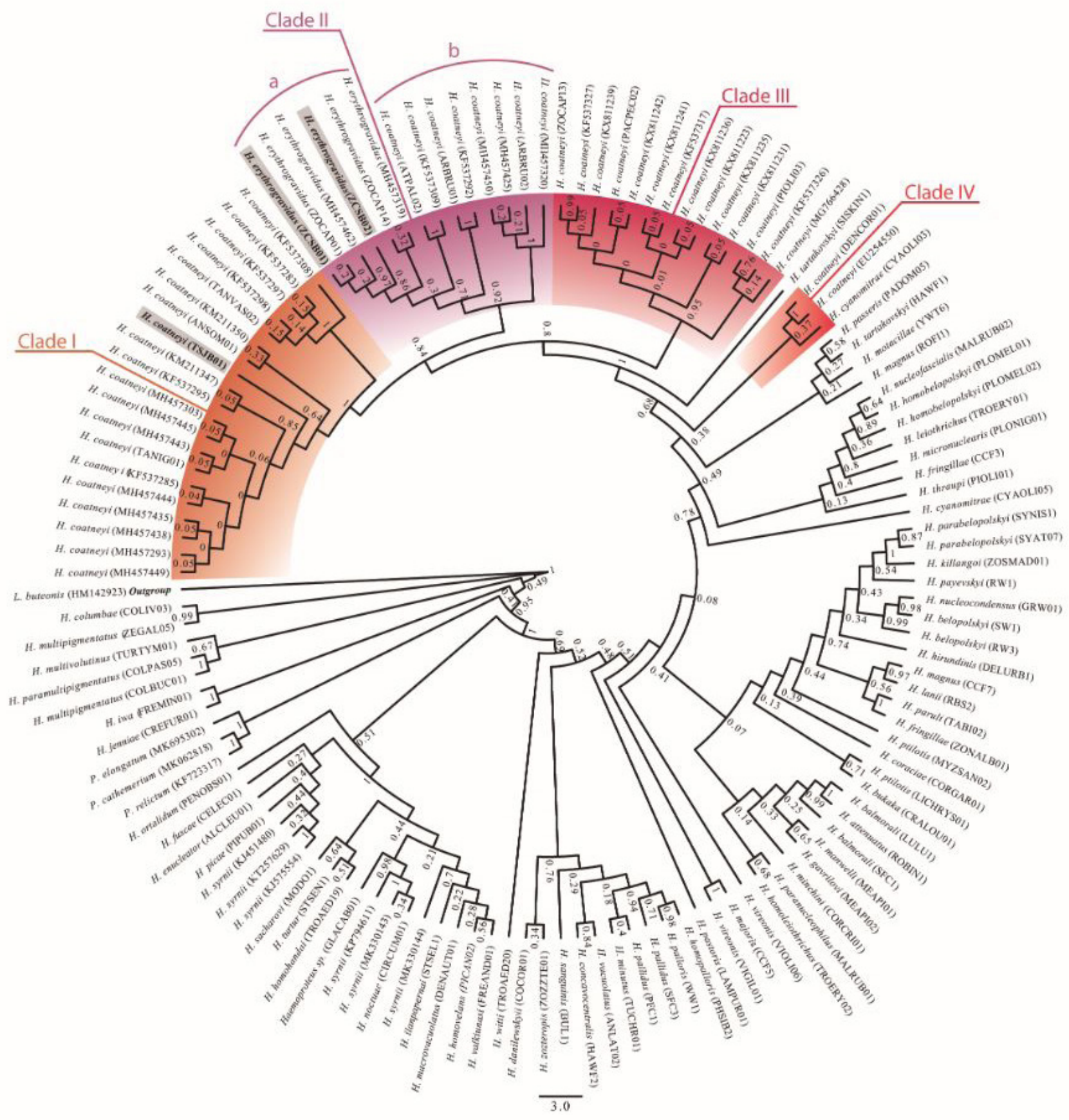

Figure 4. Bayesian Inference (BI) based on 479 bp fragments of the mitochondrial cytb gene. The sequences used in the analysis were obtained from the MalAvi and GenBank databases, whose access numbers are in parentheses. The sequences of $H$. coatneyi and $H$. erythrogravidus were gathered in four groups (Clades I - IV), one of them being formed by sequences of these two species (Clade II a-b). The sequences of the present study are given in bold font inside the gray frame. Leucocytozoon buteonis was used as outgroup.

The average genetic divergence between lineages within clades are: clade I - 0.20\% (0.00-1.91); clade II - 1.72\% (0.00-2.97); clade III - 1.86\% (0.00-2.89); clade IV - 2.82\% (0.00-4.14). The average intraspecific genetic divergence between lineages within clade II, where $H$. coatneyi and $H$. erythrogravidus lineages were found, was $1.92 \%$ (clade II-a) and $1.68 \%$ (clade II-b), respectively. The maximum intraspecific genetic divergence between the $H$. erythrogravidus lineage available in the databases and our lineages (ZCSB01 and ZCSB02) was 2.89\%, while the maximum intraspecific genetic divergence between the $H$. coatneyi lineages available in the databases and our lineage (TSJB01) was 3.10\%. The intraspecific genetic divergence between $H$. coatneyi lineages was often greater than the interspecific genetic divergence. For example, the difference between the DENCOR01 and KF537297 lineages, both 
from $H$. coatneyi, was 4.14\%, while the difference between the DENCOR01 lineage (H. coatneyi) and the CYAOLI03 lineage ( $H$. cyanomitrae) was $2.28 \%$. The genetic divergences between the lineages used in this study to perform phylogenetic analyses are listed in Figure 5.

The lineages of the present study (ZCSB01, ZCSB02 and TSJB01) and the other H. coatneyi and H. erythrogravidus lineages were recorded in the American continent, in hosts of the order Passeriformes (Figure 6). The species H. coatneyi has been found in North, Central and South America, with the largest number of records in Colombia and Peru. This is the first report of this species in Brazil. Haemoproteus erythrogravidus has been recorded only in South America, in the countries Colombia, Peru and Brazil, and in the latter country we recorded a new lineage infecting wild birds.

\section{Discussion}

In this study, morphological and molecular evidence was presented of hemoparasites of the genus Haemoproteus in wild birds of the Atlantic Forest. The phylogenetic reconstruction showed that the ZCSB01 and ZCSB02 lineages of Z. capensis and TSJB01 of T. sayaca are closely related to the H. erythrogravidus and H. coatneyi lineages, respectively. The TSJB01 lineage showed 100\% similarity with the NEOFAS02 strain, which was recorded in Neothraupis fasciata, but was not attributed to any morphospecies. This species of bird belonging to the family Thraupidae is recorded in Brazil's Cerrado biome (MalAvi, 2020; Fecchio et al., 2017). The ZCSB01 lineage showed 100\% similarity with ZOCAP01, a lineage previously associated with the H. erythrogravidus morphospecies (Mantilla et al., 2016), while the ZCSB02 lineage showed 99\% similarity with ZCSB01 and ZOCAP01, thus corresponding to a new lineage, which will therefore be added to the databases in order to facilitate new studies on these species.

Based on published sequences, the distribution of haemosporidians and their hosts showed that $H$. coatneyi is the species with the greatest geographical distribution, occurring in South, Central and North America, whereas $H$. erythrogravidus occurs only in South America. It should be noted that this paper offers the first record of $H$. coatneyi in Brazil, thus expanding the body of knowledge about the geographic distribution of this parasite. There are areas of overlap in the occurrence of the two species, which may even be using the same vectors for dispersion. These patterns of spatial distribution of the diversity of parasitic species may be related to ecologically distinct habitats, environmental variables and the abundance of vectors (Sol et al., 2000; Sehgal et al., 2011; Loiseau et al., 2012; Clark et al., 2014). It is known that parasites have a series of effects on their hosts, influencing the temporal and spatial dynamics of natural populations and bird communities (Leite et al., 2013). In addition, knowledge about the spatial distribution of parasites, when correlated with the diversity and abundance of the vector, can contribute to protect public health, since these vectors can also transmit other diseases, including those that occur in humans (Grillo, 2009).

The morphological characterization demonstrated that the gametocytes of Haemoproteus spp. identified in $T$. sayaca and in the two specimens of $Z$. capensis showed morphological similarities with the original descriptions of the gametocytes of $\mathrm{H}$. (Parahaemoproteus) coatneyi and $\mathrm{H}$. (Parahaemoproteus) erythrogravidus, respectively (Burry-Caines \& Bennett, 1992; Mantilla et al., 2016). These gametocytes also showed a slight constriction in the central part of the parasite, a rather uncommon characteristic, but which is also mentioned in the original description of $H$. coatneyi (Burry-Caines \& Bennett, 1992). In addition, some mature gametocytes from the two parasites showed a tendency to form a balloon-like protrusion on the non-parasitized side of the erythrocyte, a characteristic associated only with $\mathrm{H}$. erythrogravidus (Mantilla et al., 2016). It is known that variations may occur in the shape and number of gametocytes in Haemoproteus species when smears are produced at different times in the infection process, i.e., in acute, chronic or recurrent infections, or when the preparation of blood smears is slow and air humidity is high (Valkiūnas, 2005). However, as the smears of these birds were of good quality and they were prepared correctly, the changes observed may be ascribed to the normal progressive development of the parasites, since different forms of the same Haemoproteus species have already been observed in smears prepared at different times from the same bird (Burry-Caines \& Bennett, 1992). Thus, these two unusual characteristics are not enough to conclude that the species evaluated in this study are different from $\mathrm{H}$. coatneyi and $\mathrm{H}$. erythrogravidus.

Mantilla et al. (2016) used two morphological features to differentiate $H$. coatneyi from $H$. erythrogravidus that infected Z. capensis in Ecuador and Colombia. These features are similar to the unusual ones listed above, which were found in $T$. sayaca and $Z$. capensis (slight constriction in the central part of the parasite and balloon-like protrusion on the non-parasitic side of the erythrocyte). These characteristics have already been seen in other Haemoproteus species, such as: Haemoproteus fringillae, which had slightly visible protrusions in their envelopes and 


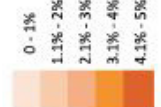

$\sqrt{2}$

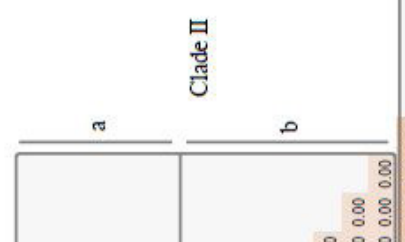

:

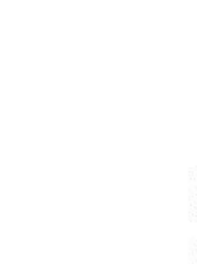

ปัँ

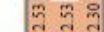

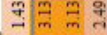

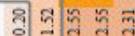

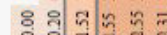

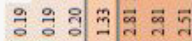

8웅영 잉

웅응 옿 형

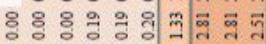

8888 영 영 영류

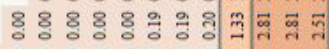

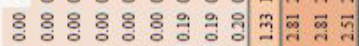

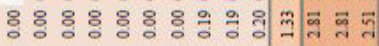

888888880900090

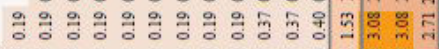

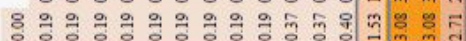

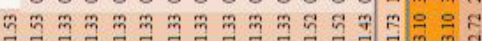

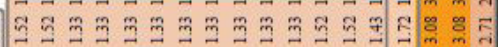

구의.

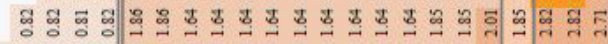

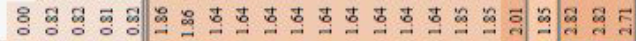

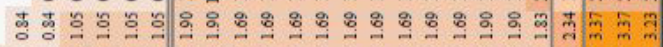

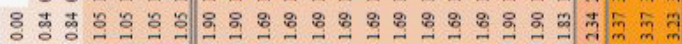

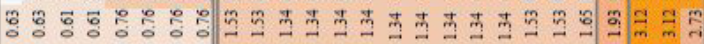

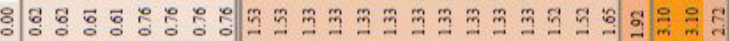

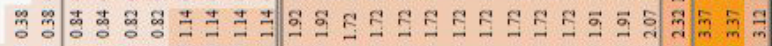

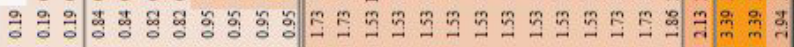

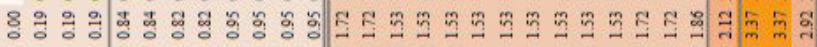

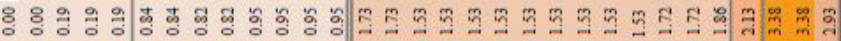

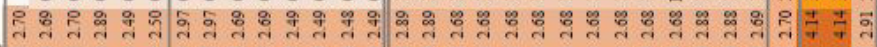

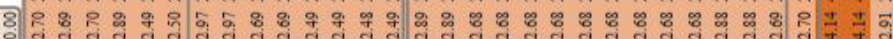

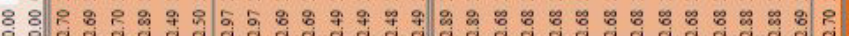

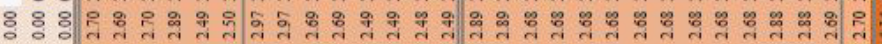

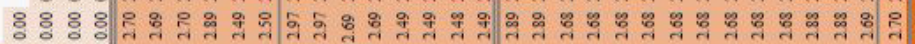

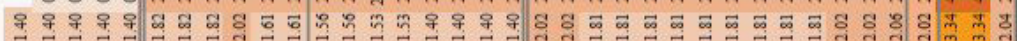

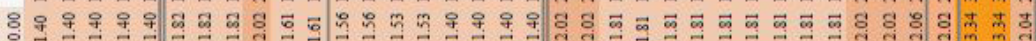

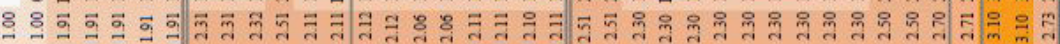

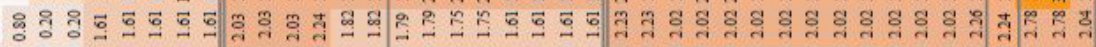

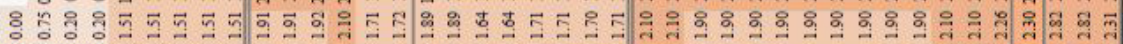

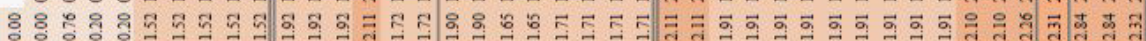

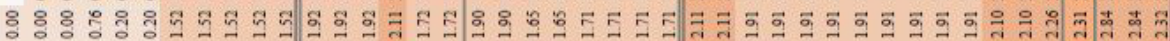

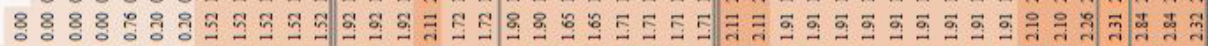

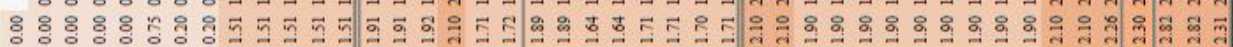

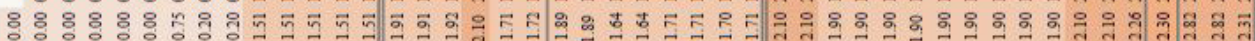

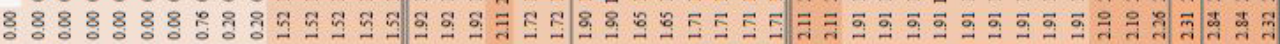

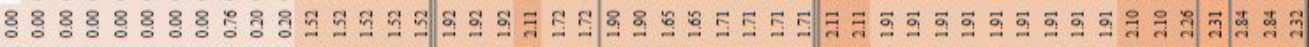

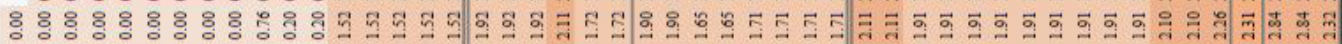

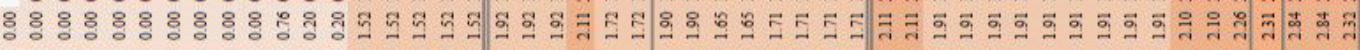

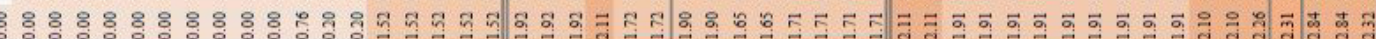

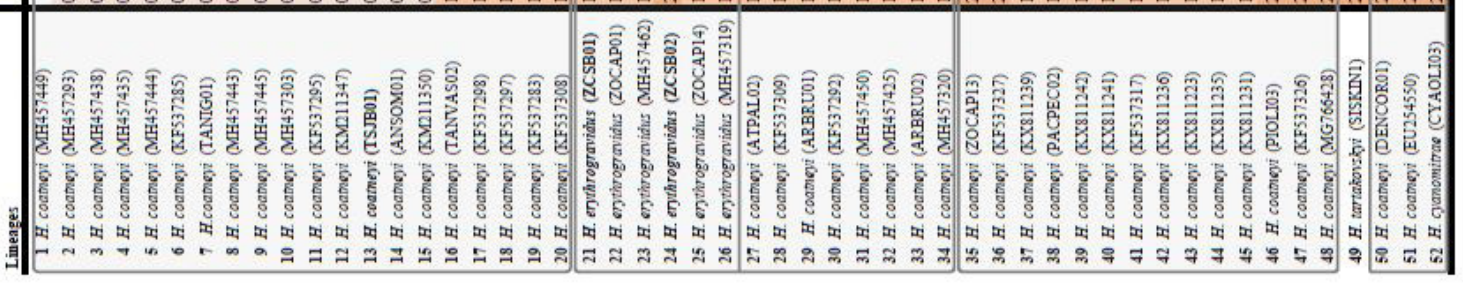

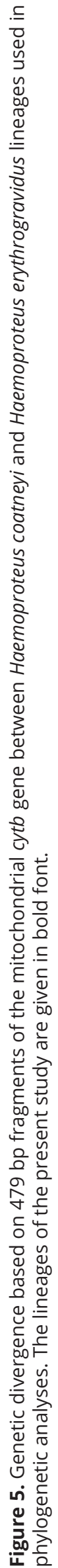




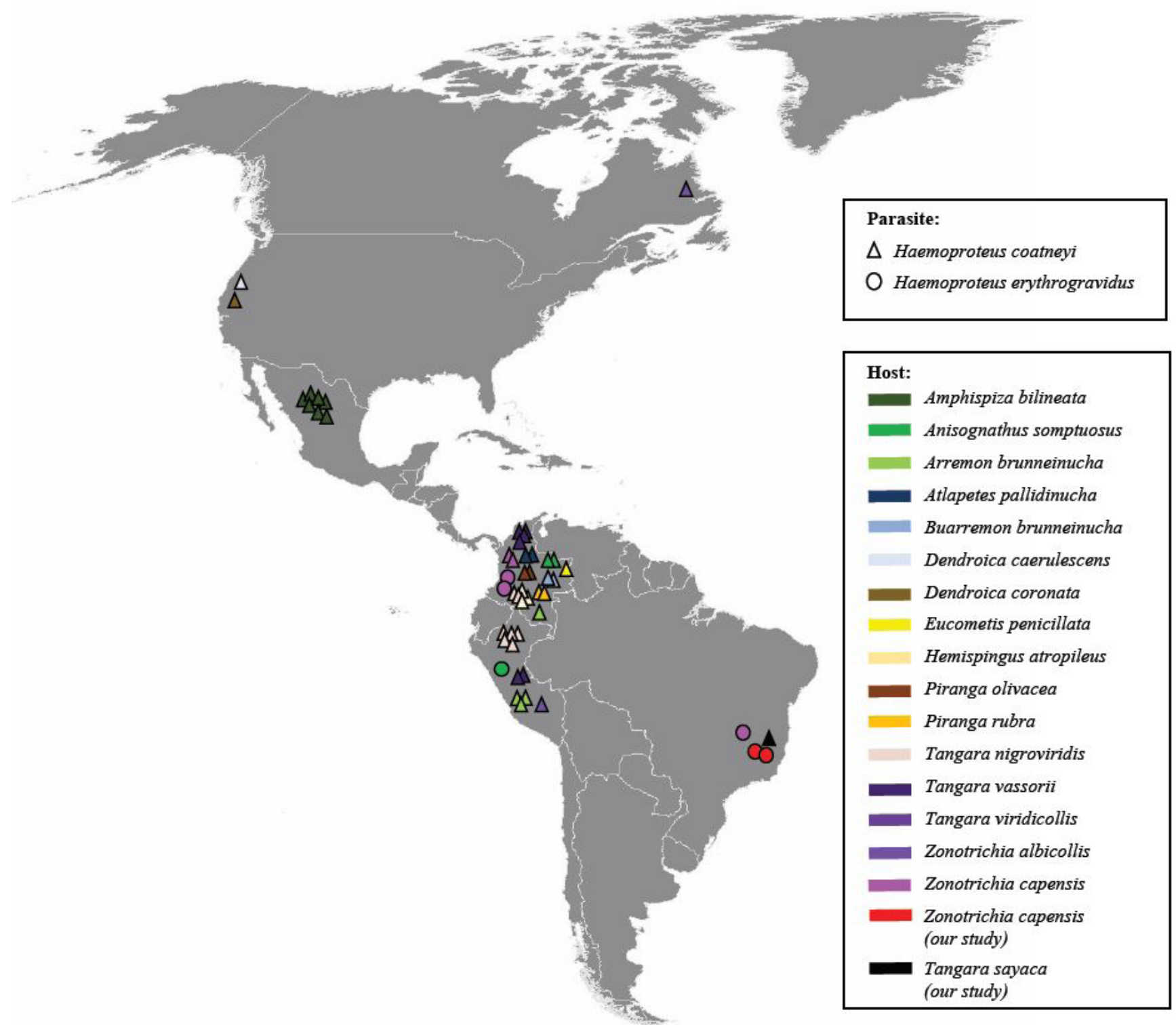

Figure 6. Hosts and geographical distribution of Haemoproteus coatneyi and Haemoproteus erythrogravidus lineages.

Haemoproteus attenuatus gametocytes, which have a markedly attenuated width in their central region, showing the dumbbell shape (Valkiūnas, 2005). Mantilla et al. (2016) stated that such protrusions were visible only in the final stages of development of gametocytes, and were less prominent; besides, the obtained $\mathrm{H}$. fringillae and H. erythrogravidus sequences were clearly genetically dissimilar, with a $4.3 \%$ to $4.5 \%$ genetic divergence based on the $479 \mathrm{bp}$ fragment of the cytb gene. The authors also stated that the feature of attenuated width was found only in $H$. attenuatus microgametocytes and that the genetic divergence of the two obtained $H$. erythrogravidus sequences was between $4.3 \%$ and $4.6 \%$ in cytb gene, which is assumed to differentiate these species.

In the present study, 50 strains of the two parasites were used to perform the phylogenetic analysis, a far larger number than that used by Mantilla et al. (2016) $(n=11)$. Thus, an average genetic distance of $0.83 \%$ was observed between the clade formed by the H. erythrogravidus lineages (clade II-a) and that formed by the H. coatneyi lineages (clade II-b), which is similar to the distance used by those authors to separate the species. According to Hellgren et al. (2007), species with a genetic distance above 5\% are generally morphologically distinct. However, these species may present a lower genetic distance, provided they are clearly differentiated morphologically or that they present a high divergence in another gene that has phylogenetic resolution, in addition to cytb gene. Thus, there are examples of haemosporidian species whose cytb gene differs by less than $1 \%$, as is the case of Haemoproteus jenniae and Haemoproteus siwa, whose cytb gene presents a genetic divergence of $0.6 \%$ and of $4 \%$ 
in a segment of the apicoplast gene, in addition to being morphologically well differentiated (Levin et al., 2012). Another example is Haemoproteus pallidus and Haemoproteus minutus, which differ by only $0.7 \%$ in the complete sequence of cytb gene, but are clearly morphologically different (Hellgren et al., 2007). Considering the low genetic divergence and the fact that the morphological characteristics used for differentiation have been observed in several other species, it's possible that $H$. erythrogravidus is not a case of speciation.

According to the molecular, morphological and spatial distribution data, it was found that both $H$. coatneyi and H. erythrogravidus are parasitizing the order Passeriformes in Brazil. These two species have very similar gametocyte morphology and low genetic divergence, and may even be intraspecific variations of these two haemosporidian species. However, future phylogeny studies using mitochondrial genes and methods of computational demarcation of species may assist in the taxonomic delimitation of these two parasites.

\section{Acknowledgements}

We thank the Instituto Estadual de Florestas (IEF) and the Instituto Brasileiro do Meio Ambiente e dos Recursos Naturais Renováveis (IBAMA) for granting us permission to collect birds. We thank the Fundação de Amparo à Pesquisa do Estado de Minas Gerais (FAPEMIG/PPM/2016; PPM-00734-16) and the Coordenação de Aperfeiçoamento de Pessoal de Nível Superior (CAPES, grant numbers 1525/2011) for their financial support of this work, and the Conselho Nacional de Desenvolvimento Científico e Tecnológico (CNPq) for granting a fellowship to LO (PhD) and a Research Productivity Grant to HAS and RJPD.

\section{References}

Bennett GF, Campbell AG. Avian Haemoproteidae. I. Description of Haemoproteus fallisi n. sp. and a review of the haemoproteids of the family Turdidae. Can J Zool 1972; 50(10): 1269-1275. http://dx.doi.org/10.1139/z72-172. PMid:4628849.

Bensch S, Stjernman M, Hasselquist D, Ostman O, Hansson B, Westerdahl H, et al. Host specificity in avian blood parasites: a study of Plasmodium and Haemoproteus mitochondrial DNA amplified from birds. Proc Bio/ Sci 2000; 267(1452): 1583-1589. http:// dx.doi.org/10.1098/rspb.2000.1181. PMid:11007335.

Burry-Caines JR, Bennett GF. The Haemoproteidae (Apicomplexa: Haemosporina) of the avian families Fringillidae and Emberizidae s.I. Can J Zool 1992; 70(6): 1149-1160. http://dx.doi.org/10.1139/z92-161.

Clark NJ, Clegg SM, Lima MR. A review of global diversity in avian haemosporidians (Plasmodium and Haemoproteus: Haemosporida): new insights from molecular data. Int J Parasitol 2014; 44(5): 329-338. http://dx.doi.org/10.1016/j.ijpara.2014.01.004. PMid:24556563.

Dimitrov D, lezhova TA, Zehtindjiev P, Bobeva A, Ilieva M, Kirilova M, et al. Molecular characterisation of three avian haemoproteids (Haemosporida, Haemoproteidae), with the description of Haemoproteus (Parahaemoproteus) palloris n. sp. Syst Parasitol 2016; 93(5): 431-449. https://doi.org/10.1007/s11230-016-9638-8.

Dimitrov D, Zehtindjiev P, Bensch S, Ilieva M, lezhova TA, Valkiūnas G. Two new species of Haemoproteus Kruse, 1890 (Haemosporida, Haemoproteidae) from European birds, with emphasis on DNA barcoding for detection of haemosporidians in wildlife. Syst Parasito/ 2014; 87(2): 135-151. http://dx.doi.org/10.1007/s11230-013-9464-1. PMid:24474037.

Fecchio A, Pinheiro R, Felix G, Faria IP, Pinho JB, Lacorte GA, et al. Host community similarity and geography shape the diversity and distribution of haemosporidian parasites in Amazonian birds. Ecography 2017; 41(3): 505-515. http://dx.doi.org/10.1111/ ecog.03058.

Garnham PC. Malaria parasites and other Haemosporidia. Oxford: Blackwell Scientific Publications; 1966.

GenBank. GenBank: the NIH genetic sequence database [online]. Bethesda: NCBI; 2020 [cited 2020 Mar 26]. Available from: https:// www.ncbi.nlm.nih.gov/genbank/

Grillo E. Presence of haemosporidia and flaviviruses in breeding prothonotary warblers (Protonotaria citrea): an analysis of spatial and temporal trends in infection prevalence and associations with reproductive success [thesis]. Virginia: Virginia Commonwealth University; 2009.

Hellgren O, Krizanauskiene A, Valkiūnas G, Bensch S. Diversity and phylogeny of mitochondrial cytochrome $b$ lineages from six morphospecies of avian Haemoproteus (Haemosporida: Haemoproteidae). J Parasitol 2007; 93(4): 889-896. http://dx.doi. org/10.1645/GE-1051R1.1. PMid:17918371.

Hellgren O, Waldenstrom J, Bensch S. A new PCR assay for simultaneous studies of Leucocytozoon, Plasmodium, and Haemoproteus from avian blood. J Parasitol 2004; 90(4): 797-802. PMid:15357072. 
Katoh K, Rozewicki J, Yamada KD. MAFFT online service: multiple sequence alignment, interactive sequence choice and visualization. Brief Bioinform 2019; 20(4): 1160-1166. http://dx.doi.org/10.1093/bib/bbx108. PMid:28968734.

Kumar S, Stecher G, Li M, Knyaz C, Tamura K. MEGA X: molecular Evolutionary genetics analysis across computing platforms. Mol Biol Evol 2018; 35(6): 1547-1549. http://dx.doi.org/10.1093/molbev/msy096. PMid:29722887.

Leite YFC, Pinheiro RT, Braga EM. Prevalência de Hemosporideos em três localidades do Estado do Tocantins, Brasil. Ornithologia 2013; 6(1): 1-13.

Levin II, Valkiūnas G, lezhova TA, O’Brien SL, Parker PG. Novel Haemoproteus species (Haemosporida: Haemoproteidae) from the swallow-tailed gull (Lariidae), with remarks on the host range of hippoboscid-transmitted avian hemoproteids. J Parasitol 2012; 98(4): 847-854. http://dx.doi.org/10.1645/GE-3007.1. PMid:22324933.

Loiseau C, Harrigan RJ, Robert A, Bowie RCK, Thomassen HA, Smith TB, et al. Host and habitat specialization of avian malaria in Africa. Mol Ecol 2012; 21(2): 431-441. http://dx.doi.org/10.1111/j.1365-294X.2011.05341.x. PMid:22142265.

MalAvi. MalAvi: a database for avian haemosporidian parasites [online]. 2020 [cited 2020 Mar 26]. Available from: http://130.235.244.92/Malavi/

Mantilla JS, González AD, Lotta IA, Moens M, Pacheco MA, Escalante AA, et al. Haemoproteus erythrogravidus n. sp. (Haemosporida, Haemoproteidae): description and molecular characterization of a widespread blood parasite of birds in South America. Acta Trop 2016; 159: 83-94. http://dx.doi.org/10.1016/j.actatropica.2016.02.025. PMid:26995696.

Martinsen ES, Perkins S, Schall JJ. A three-genome phylogeny of malaria parasites (Plasmodium and closely related genera): evolution of life-history traits and host switches. Mol Phylogenet Evol 2008; 47(1): 261-273. http://dx.doi.org/10.1016/j.ympev.2007.11.012. PMid:18248741.

Ridgely RS, Tudor G. Field guide to the songbirds of South America: the passerines. Austin: University of Texas Press; 2009.

Rodrigues RA, Massara RL, Bailey LL, Pichorim M, Moreira PA, Braga EM. Using a multistate occupancy approach to determine molecular diagnostic accuracy and factors afecting avian haemosporidian infections. Sci Rep 2020; 10(1): 8480. http://dx.doi. org/10.1038/s41598-020-65523-X. PMid:32439889.

Ronquist F, Teslenko M, van der Mark P, Ayres DL, Darling A, Höhna S, et al. MrBayes 3.2: efficient Bayesian phylogenetic inference and model choice across a large model space. Syst Bio/ 2012; 61(3): 539-542. http://dx.doi.org/10.1093/sysbio/sys029. PMid:22357727.

Sanger F, Nicklen S, Coulson AR. DNA sequencing with chain-terminating inhibitors. Proc Natl Acad Sci USA 1977; 74(12): 54635467. https://dx.doi.org/10.1073\%2Fpnas.74.12.5463 PMid:271968.

Santiago-Alarcon D, Outlaw DC, Ricklefs RE, Parker PG. Phylogenetic relationships of haemosporidian parasites in New World Columbiformes, with emphasis on the endemic Galapagos dove. Int J Parasito/ 2010; 40(4): 463-470. http://dx.doi.org/10.1016/j. ijpara.2009.10.003. PMid:19854196.

Sehgal RNM, Buermann W, Harrigan RJ, Bonneaud C, Loiseau C, Chasar A, et al. Spatially explicit predictions of blood parasites in a widely distributed African rainforest bird. Proc Bio/ Sci 2011; 278(1708): 1025-1033. http://dx.doi.org/10.1098/rspb.2010.1720. PMid:20880888.

Sigrist T. Avifauna Brasileira. São Paulo: Avis Brasilis; 2014.

Sol D, Jovani R, Torres J. Geographical variation in blood parasites in feral pigeons: the role of vectors. Ecography 2000; 23(3): 307-314. http://dx.doi.org/10.1111/j.1600-0587.2000.tb00286.x.

Talavera G, Castresana J. Improvement of phylogenies after removing divergent and ambiguously aligned blocks from protein sequence alignments. Syst Biol 2007; 56(4): 564-577. http://dx.doi.org/10.1080/10635150701472164. PMid:17654362.

Tavaré S. Some probabilistic and statistical problems in the analysis of DNA sequences. In: Miura RM, editor. Lectures on mathematics in life sciences. Rhode Island: American Mathematical Society; 1986. p. 57-86.

Valkiūnas G, Ashford RW. Natural host range is not a valid taxonomic character. Trends Parasito/ 2002; 18(12): 528-529. http:// dx.doi.org/10.1016/S1471-4922(02)02429-7. PMid:12482535.

Valkiūnas G, lezhova TA. Keys to the avian malaria parasites. Malar J 2018; 17(1): 212. http://dx.doi.org/10.1186/s12936-0182359-5. PMid:29843718.

Valkiūnas G. Avian malaria parasites and other haemosporidia. Florida: CRC Press Boca Raton; 2005.

Yang Z. Maximum likelihood phylogenetic estimation from DNA sequences with variable rates over sites: approximate methods. J Mol Evol 1994; 39(3): 306-314. http://dx.doi.org/10.1007/BF00160154. PMid:7932792. 